\title{
Editorial Editorial
}

GALILEU - REVISTA DE DIREITO E ECONOMIA - e-ISSN 2184-1845

Volume XXI $\cdot 1^{\text {st }}$ January Janeiro $-31^{\text {th }}$ June Junho $2020 \cdot$ pp. 6

DOI: http://doi.org/10.26619/2184-1845.XXI.1.1.1

Este número, onde nos propusemos assumir plenamente a digitalização da nossa revista para uma melhor e mais ampla difusão, acabou por coincidir com a crítica situação de pandemia em que o mundo se encontra, reafirmando a pertinência da opção adoptada. Com efeito, pese embora as restrições ambulatórias, o encerramento de estabelecimentos e/ou os confinamentos decretados, o conhecimento e a ciência jurídica continuam a fluir livremente pelos meios digitais, o que muito nos satisfaz.

Conforme vem sendo habitual, apresentam-se diversos artigos de investigação científica no domínio jurídico, com a especial e actual oportunidade de abordar, além de outras matérias, o regime jurídico do trabalho em tempos de pandemia. Com o ensejo de enriquecer o contributo da revista para a sociedade, apresentam-se também trabalhos mais informais correspondentes a arguições de teses de doutoramento e ainda o comentário à recente jurisprudência ou outras notícias de teor jurídico cuja actualidade e relevância mereceram a nossa atenção.

Agradecemos todos os contributos dos autores cujos trabalhos são alvo da presente publicação, estendendo um novo convite a todos aqueles que queiram contribuir com os seus trabalhos, originais, inéditos e relevantes, nos próximos números da revista Galileu.

Muita saúde e uma boa leitura!

O Diretor da Galileu Ruben Bahamonde Delgado 